\title{
A participation model based on community forum as a reproductive health knowledge transaction space to increase male participation in vasectomy
}

\author{
Model peningkatan partisipasi KB Vasektomi pria berbasis forum warga \\ sebagai ruang transaksi pengetahuan kesehatan reproduksi
}

\author{
$\underline{\text { Noverman Duadji }}^{1,2} \&$ Novita Tresiana ${ }^{1,2}$ \\ ${ }^{1}$ Department of Public Administration, Faculty of Social and Political Science, Universitas Lampung \\ ${ }^{2}$ Universitas Lampung and Research and Development Center for Women, Child, and \\ Development LPPM Universitas Lampung \\ Jalan Soemantri Brojonegoro No. 1, Bandar Lampung, Lampung 35141 \\ E-mail: novermanduadji@yahoo.co.id; novitatresiana@yahoo.co.id
}

\begin{abstract}
The first background of this research is the low participation of male vasectomy $K B$ due to lack of information and low male contraceptive services. The second background of this research is Friedmann's (2011) idea of citizen forum as transaction space which becomes communication media in the form of equal dialogue. This study aims to analyse the causes of low participation in the vasectomy method of family planning $(K B)$ in South Lampung Regency; analyse the grassroots organisations in the community as the support system for a potential increase in the society's participation in vasectomy as a part of family planning $(K B)$; and develop a model of vasectomy to increase the participation in South Lampung Regency. This study utilised primary and secondary data which were collected and analysed using qualitative-descriptive method. The research was conducted in nine villages in South Lampung Regency. The findings showed that the major failure for participation in the vasectomy method of family planning $(K B)$ was caused by a lack of a representative knowledge transaction space in family planning $(K B)$ and reproductive health. On the other hand, the existing active societal-institutional support system can be utilised as the space for knowledge transaction. A solution to enhance a social participation model through community forums is urgently needed.
\end{abstract}

Keywords: participation; community forum; knowledge transactions

\begin{abstract}
Abstrak
Latar belakang penelitian ini yang pertama adalah rendahnya partisipasi KB vasektomi pria karena minimnya informasi dan rendahnya layanan KB pria. Latar belakang penelitian kedua adalah adanya gagasan Friedmann (2011) mengenai forum warga sebagai ruang transaksi yang menjadi media komunikasi dalam bentuk dialog yang berkesetaraan. Penelitian ini bertujuan untuk mengkaji faktor penyebab rendahnya partisipasi KB vasektomi di Kabupaten Lampung Selatan; menganalisis kelembagaan-kelembagaan kemasyarakatan yang ada di masyarakat sebagai daya dukung dalam peningkatan partisipasi KB vasektomi; dan mengembangkan model peningkatan partisipasi KB vasektomi di Kabupaten Lampung Selatan. Data yang digunakan adalah data data primer dan sekunder. Data yang dikumpulkan, dianalisis kualitatif deskriptif. Lokasi penelitian adalah 9 desa di Kabupaten Lampung Selatan. Hasil penelitian menunjukkan kegagalan utama partisipasi $K B$ vasektomi disebabkan ketiadaan ruang sebagai transaksi pengetahuan KB dan kesehatan reproduksi yang representatif, di sisi lain ada daya dukung kelembagaan kemasyarakatan lokal hidup dan aktif, dan bisa dimanfaatkan sebagai ruang transaksi pengetahuan. Diperlukan solusi berupa model peningkatan partisipasi melalui forum warga.
\end{abstract}

Kata kunci: partisipasi; forum warga; transaksi pengetahuan

\section{Introduction}

This research on male participation in vasectomy method of family planning (hereafter, $K B$ ) and community forum was conducted due to these following considerations. Firstly, low male participation in vasectomy method of $K B$ is alledgedly caused by the lack of information and sufficient service 
on $K B$ for male. Some socializations have been conducted, yet it has not succeeded in improving male participation in $K B$. Based on Lampung Province's $B K K B N$ report (2014), it was revealed that there were merely 3.543 people participating in vasectomy method of $K B$ in the last four years. In details, there were 773 people from Bandar Lampung municipal, 98 people from Central Lampung Regency, and 83 people from Pringsewu Regency who were recorded as the acceptors of vasectomy. Subsequently, the fourth and fifth place of the highest participation rate were recorded by Tanggamus and Tulangbawang Regencies with 78 and 63 people respectively. The rank was followed by North Lampung Regency with 52 vasectomy acceptors and Way Kanan Regency with 48 acceptors. While the lowest participation ranks were recorded by Lampung Regency with 29 people, Mesuji with 13 people, and East Lampung with merely three people. Vasectomy acceptors were mostly males from lower classes. At least 60 percent (or 2, 125 people) of the overall 3,543 vasectomy acceptors in Lampung were males from lower classes within the society, such as becak (pedicab) riders, farmers, fishermen, or ojek (motorcycle transport) riders. This data reveals that on one hand, $K B$ purpose is indeed to control population growth, including lessening poverty rate among society, because most underprivileged family generally have more than three children. Such condition creates more burden for family's economic situation. This economic factor drives males from underprivileged families to disregard a taboo of participating in a permanent $K B$ program. However, it is also possible and expected that vasectomy acceptors may come from middle or upper classes, such as society's prominent figures, businessmen, civil servants, and many others. Secondly, a suggestion of community forum as a transaction space (Friedman, 2011:26) may be implemented to enhance participation in $K B$ and serve as a communication media in terms of an equal dialogue. Every community member, both male and female, shall sit together respectfully while exchanging information and empathy, so that reciprocal and mutually beneficial relationship can be established.

Choosing male participation in vasectomy method of $K B$ as the research topic was based on several considerations. Firstly, an understanding that $K B$, as a part of reproductive health based on the International Conference on Population and Development (ICPD) in Cairo 1994, is a basic, individual right for both male and female regarding their respective reproductive health; thus, it is tightly related to human right. Referring to the aforementioned conference, both male and female posses equal reproduction rights, including participation in family planning programs. Secondly, a male is a sexual and reproductional partner for female; hence, it is undeniable that both share an equal responsibility and role to achieve satisfaction in their sexual lives, as well as equal burden to prevent any $K B$ related diseases and complications. Moreover, a male is also socially and economically responsible, particularly for his children, so his involvement in any reproductive decisions develops a stronger bond between him and his offspring. A male is realistically involved in fertility matter and plays an important role in deciding on a contraception method either for himself or his wife, as well as providing support for his spouse's reproduction life, namely during (or after) her pregnancy and breastfeeding period.

A development policy/program to increase $K B$ participation in South Lampung was tarnished by failure due to low society participation, both for males and females. A research conducted by Duadji $\&$ Tresiana (2015:75) found that the failures were caused by society participation model in $K B$ which proritized politics and administrative models. Moreover, the models failed to prepare a framework and mechanism for equal participations between male and female, as well as to develop an alternative model for society empowerment. Sutinah (2017:298) described that low participation rate for male vasectomy method of $K B$ was caused by an assumption that $K B$ is female's responsibility. It was also caused by the lack of knowledge among males on erection disfunction and impotence; fear of public-shaming and economic reasons; perceived high-cost for vasectomy; and blatant unwillingness (as vasectomy leads to a difficulty for male to bear more child in case they want another one in the future). Therefore, Couples of Childbearing Age (PUS) tend to prefer female-oriented contraception, such as pills, IUD, injections, and implants.

The main essence of this study is to propose a correct understanding on vasectomy participation among males under the context of reproductive health and gender equality. Male participation in $K B$ 
is also a part of the fulfillment of reproductive rights and reproductive health. Within those contexts, it includes the fulfillment of male rights to gain information and access for a safe, effective, affordable, acceptable $K B$ service of his choice, as well as rights to other birth control measures which do not violate law, ethics, and social values (Duadji \& Tresiana 2015:5). Some failures of $K B$ policies for male in South Lampung Regency call for a more serious effort to improve $K B$ implementation. One of the successful means is by fostering society's commitment to involve in it through a public space as a knowledge transaction place for a representative and familiar reproductive health knowledge to increase male participation in $K B$. A previous study by Huruta \& Sasongko (2016:212) illustrated the significance of "a space" as a place or media created by Mbatakapidu community to accommodate both utilized and not-utilized region potential, so that an existing "space", in the form of local institution, can be capitalized to respond to some challenges in improving social and economic welfare. Tresiana \& Duadji (2016:192) specifically illustrated such space as a deliberative forum, where every community member communicate to each other based on thematical issues according to their respective knowledge and capacity. It becomes a new space due to its unique and potential characteristics to construct trust and social capital between society members or with local government. Healey (1997:125) and Friedmann (1987:95) placed an understanding in a transactive planning space, referring to not only plan-making, but also a process of learning together. This model planning does not emphasize on the blue print, but on the dialogue and its results.

This study explains about three main concerns: 1) mapping the central factors which cause low male participation for vasectomy method of $K B$ in South Lampung Regency; 2) mapping the existing grassroots organizations as the supporting systems to increase participation in male vasectomy method of $K B$ in South Lampung regency; and 3) developing a model to increase participation in male vasectomy method in South Lampung Regency. This study aims to contribute to gender study development, particularly on reproductive health in terms of $K B$ policy which is positioned toward a direct participation and society empowerment. Moreover, it may be beneficial to recommend a model of $K B$ participation; thus, this model is expected to be the best practice in other regions with similar characteristics.

\section{Research Method}

This research employed qualitative research method. The research object was directed toward the attempts to improve male active participation in vasectomy method of $K B$ as a part of reproductive right implementation and reproductive health which reflect gender equality and justice. This research used both primary and secondary data. The secondary data was obtained from the relevant archive of regional government; while the primary data were obtained from interview and observation. Data collection was conducted through: 1) observation; 2) in-depth interview; 3) documents; and 4) focus group discussion. The data were then collected and analyzed qualitatively using interactive model from Miles \& Huberman (1992:81). This research encompassed 9 selected villages in South Lampung regency, namely Karang Anyar, Budi Lestari, Jati Mulyo, Margo Mulyo, Merak Batin, Pancasila, Pemanggilan, Way Galih, and Suka Marga.

\section{Results and Discussion}

\section{Analysis of the cause factors of low vasectomy participation among males}

Male participation in Family Planning Program $(K B)$, particularly for vasectomy, has been few. Based on the data from the Head of Family Planning Division in $B K K B N$ Lampung, male participation rate was merely $1.5 \%$ from the total participants of family planning program in Lampung. All these while, males merely participated in $K B$ program through vasectomy; however, the rate remained relatively low (Duadji \& Tresiana 2015:38). Table 1 below depicts the participation rate of vasectomy in South Lampung.

Based on the analyses from Table 1 and Table 2, we can map the main causes of low male participation in vasectomy, namely 1) lack of knowledge in $K B$ and reproductive health; 2) lack of information 
exchange; 3) non-existent representative forum; 4) support from informal figures in society. Public space in the form of rural government instruction was not perceived as an effective stimulant. However, the instructions and motivations from local and indigenous leaders were considered as the key stimulants in improving male participation in vasectomy method of $K B$. In line with the previous researches of Healey (1997:125) and Friedmann (1987:95), there is a need of space to mobilize understand, knowledge, arguments, and ideas to construct equality in reproductive rights.

Table 1.

Active vasectomy participation in South Lampung regency

\begin{tabular}{clcc}
\hline No & \multicolumn{1}{c}{ Village origins } & Economy Category & Total \\
\hline 1 & Karang Anyar village & Middle class & 2 \\
\hline 2 & Budi Lestari village & Lower class (poor) & 3 \\
\hline 3 & Jati Mulyo village & Lower class (poor) & 4 \\
\hline 4 & Margo Mulyo village & Lower class (poor) & 3 \\
\hline 5 & Merak Batin village & Lower class (poor) & 3 \\
\hline 6 & Pancasila village & Middle class & 1 \\
\hline 7 & Pemanggilan village & Lower class (poor) & 5 \\
\hline 8 & Way Galih village & Lower class (poor) & 3 \\
\hline 9 & Suka Marga village & Lower class (poor) & 5 \\
\hline & & Total & \\
\hline
\end{tabular}

Source: Duadji \& Tresiana 2015

Table 2.

The cause factor of low vasectomy participation

\begin{tabular}{clc}
\hline No & \multicolumn{1}{c}{ Cause Factors } & Percentage \\
\hline 1 & Lack of knowledge, awareness, attitude, and practicality among male & $25 \%$ \\
\hline 2 & Income and education & $2 \%$ \\
\hline 3 & Male perception on the value of children & $1 \%$ \\
\hline 4 & Limited accessibility and information source about male contraception & $10 \%$ \\
& service & \\
\hline 5 & Lack of health officers & $2 \%$ \\
\hline 6 & Circumstance factors: social, society culture (religion), and family/spouse & $8 \%$ \\
\hline 7 & Limited contraception tool for men & $2 \%$ \\
\hline 8 & $\begin{array}{l}\text { Non-existent instruction and motivation from society figures and } \\
\text { indigenous leaders }\end{array}$ & $25 \%$ \\
\hline 9 & Non-existent representative and familiar information forum & $25 \%$ \\
\hline & \multicolumn{2}{l}{ Total }
\end{tabular}

Source: Duadji \& Tresiana 2015

\section{Analyses of grassroots organizations as the support systems in improving participation forum for male vasectomy}

The findings of Duadji \& Tresiana (2015:48-50) generally encompassed local organizations in South Lampung, including diversed space, actors, organizational forms with varying degree of formality, autonomy, and power. The arena of grassroots organization was frequently immaterialized in charity organization, non-state development organizations, communities (associations, assemblage, customary institutions), women organizations, religious-based organizations, professional associations, labor unions, self-help groups, social movements, business associations, coalitions, and advocation groups. Shortly, all kinds of institutions, beside state-owned organization and private 
organization, can be categorized as grassroots organizations.

Table 3.

The number and forms of grassroots organizations in South Lampung

\begin{tabular}{|c|c|c|c|c|c|c|c|c|c|c|}
\hline \multirow{4}{*}{$\begin{array}{c}\text { Regency } \\
\begin{array}{c}\text { South } \\
\text { Lampung }\end{array}\end{array}$} & \multicolumn{8}{|c|}{ Organization/Institution Form } & & \\
\hline & \multicolumn{2}{|c|}{$\begin{array}{c}\text { Civil Society } \\
\text { Organization (LSM) }\end{array}$} & \multicolumn{2}{|c|}{$\begin{array}{l}\text { Societal } \\
\text { Organization } \\
\text { (ORMAS) }\end{array}$} & \multicolumn{2}{|c|}{$\begin{array}{l}\text { Regional } \\
\text { Govemment } \\
\text { Organization }\end{array}$} & \multicolumn{2}{|c|}{$\begin{array}{l}\text { Indigieneous } \\
\text { Organizations }\end{array}$} & \multicolumn{2}{|c|}{ TOTAL } \\
\hline & Num & $\%$ & Num & $\%$ & Num & $\%$ & Num & $\%$ & Num & $\%$ \\
\hline & 66 & 11.8 & 120 & 21.5 & 7 & 1.3 & 365 & 65.4 & 558 & 100 \\
\hline
\end{tabular}

Table 3 above depicts the mapping and registration of grassroots organizations in South Lampung Regency based on its deed of establishment (notarial deed) and official report of organizational committee to the Institution of National and Political Unity (Bakesbangpol) in the regency. Based on the registration of Bakesbangpol in South Lampung, until July 2014, 66 civil society organization (CSO/LSM) and 120 societal organization (ORMAS) were recorded to have deeds of establishment (notarial deeds). However, on the other hand, the research team managed to record 365 indigenous organizations and seven regional government institution which have yet recorded in Kesbangpol, because they are not considered as official organizations. Based on its bureaucratic process, besides institutions with a parent institution at national, provincial, and municipal level, the establishment of civil society organization and societal organization in South Lampung was mostly initiated by sharing ideas and limited discussions among several elites to agree on and formulate the organization's name, fields, objectives, and committee. Next, those people composed a deed of establishment in a notary office and officially registered the organizational committee in local Kesbangpol. Therefore, a local organization did not actually depart from issues, needs, and daily lives of their own society to a more institutionalized form aiming to strengthen its own network, structure, and activism in the future; but it actually put an institutionalization process first, then decided on its institutional activities and orientation after. It similarly goes with member recruitment which was only conducted after the organization had been legalized (through notarial deed); yet sometimes the organization preferred not to recruit any members, so its institutional activities were largerly run by and depended on its core committee.

Table 4 illustrates the relationship between local organizations in South Lampung regency and founding figures' professions and backgrounds. It breaks down that $32.27 \%$ grassroot organizations were established by political party committee; $6.48 \%$ by political party partisans; $53.88 \%$ by activists and non-party society figures; and $7.37 \%$ by civil servants or retiree. Based on Gaventa \& Valderama's (2001:72) posit about citizen participations, it can be explained that participation's context and substance, as well as affiliation pattern (bond), in South Lampung regency inclined toward activities-oriented.

Table 5 depicts that civil society's affiliation pattern was recorded at $6.06 \%$ and its activities were positioned toward mass movement participation pattern. Its patterns, such as mobilization, activism, and mass demonstration, aimed to blow up some public issues, as well as to criticized and put pressure on regional government's policy. There was $4.55 \%$ of its activism which was recorded as democratic participation in government (PDP). It was considered as an activity to represent a component (element) of the community in planning and budgeting development program, from administrative village/musrenbang level, to sub-district level and district level. Unfortunately, this pattern was still characterized based on regional government's mandate, so the relationship was rather spontaneous and short-term; thus, the benefits obtained were restricted to self-interest fulfillment and elite alliance, unrelated to substantial public issues for wider audience. Moreover, there was $89.4 \%$ civil society organization (CSO) participated in community participation (PK) form. These CSOs acquired mandates from regional government for a hearing session in front of legislative 
and executive members on public issues, or given mandate to observe governance process and development program in their respective regions. This pattern was limited to a movement to fulfill the right to express opinion and to declare a statement as a community forum to observe governance process and implementation of development program.

Table 4.

Relationship between founding figures' profession and background and local organization/institution

\begin{tabular}{|c|c|c|c|c|c|c|c|c|c|c|c|}
\hline \multirow{3}{*}{ Regency } & \multicolumn{9}{|c|}{ Founding Figures } & \multirow{2}{*}{\multicolumn{2}{|c|}{ Total }} \\
\hline & \multirow[t]{2}{*}{$\begin{array}{l}\text { Organization } \\
\text { Form }\end{array}$} & \multicolumn{2}{|c|}{$\begin{array}{c}\text { Party } \\
\text { Committee }\end{array}$} & \multicolumn{2}{|c|}{$\begin{array}{c}\text { Party } \\
\text { Partisan }\end{array}$} & \multicolumn{2}{|c|}{$\begin{array}{c}\text { Activist } \\
\text { and Society } \\
\text { Figures } \\
\text { (non-party) }\end{array}$} & \multicolumn{2}{|c|}{$\begin{array}{c}\text { Civil } \\
\text { Servant } \\
\text { (or retiree) }\end{array}$} & & \\
\hline & & Num & $\%$ & Num & $\%$ & Num & $\%$ & Num & $\%$ & Num & $\%$ \\
\hline \multirow{5}{*}{$\begin{array}{c}\text { South } \\
\text { Lampung }\end{array}$} & $\begin{array}{l}\text { Civil Society } \\
\text { Organization } \\
(L S M)\end{array}$ & 37 & 56.06 & 9 & 13.64 & 13 & 19.70 & 7 & 10.61 & 66 & 100 \\
\hline & $\begin{array}{c}\text { Societal } \\
\text { Organization } \\
\text { (ORMAS) }\end{array}$ & 103 & 85.83 & 2 & 1.67 & 9 & 7.50 & 6 & 5.00 & 120 & 100 \\
\hline & $\begin{array}{l}\text { Regional } \\
\text { Government } \\
\text { Organization }\end{array}$ & 2 & 28.57 & 1 & 14.29 & 0 & - & 4 & 57.14 & 7 & 100 \\
\hline & $\begin{array}{c}\text { Indigenous } \\
\text { Organizations }\end{array}$ & 4 & 1.10 & 11 & 3.01 & 338 & 92.60 & 12 & 3.29 & 365 & 100 \\
\hline & Total & 146 & 26.16 & 23 & 4.12 & 360 & 64.52 & 29 & 5.20 & 558 & 100 \\
\hline
\end{tabular}

Meanwhile, for 120 ORMAS and 365 indigenous organizations in South Lampung Regency, 100\% of their activities were directed toward community participation. They usually obtained mandates from regional government for a hearing, statement declaration, and observation on their respective regions' governance and development programs. This pattern's characters remained restricted to a spontaneous movement for society's rights fulfillment and constitutional freedom to gather, form a union, and offering opinions on their own issues. Meanwhile, for seven institutions/organizations formed by regional government, the affiliation patterns were more oriented toward democratic participation in government (PDP). Even though these organizations attempted to form a strategic alliance by involving themselves in planning, budgeting, and monitoring/evaluation process of development programs, yet they were more inclined to be represented as the instruments of regional government's power to balance CSOs, societal organizations, and indigenous organizations formed by society. Therefore, the strategic alliance was rather pseudo in form and did not substantially voice out and fight for public interest.

If local institutional values were connected to social, economic, and political contexts in South Lampung regency, then the data in Table 6 above follow the value trends. Firstly, the value trends of CSOs, ORMAS, and regional government organizations still socially inclined toward elite interest as the balancer of societal power. However, they politically play roles as issue makers, government's power instrument, and in interest-sharing or negotiation. Secondly, indigenous organizations were more socially inclined toward values like tightly-knitted relations, harmony, tolerance, community self-help, kinship, cultural and ethnical attachment, social awareness, and obedience toward indigenous leaders. While politically, their participations remained limited to providing suggestion, declaring statement, and participating in democratic parties. Thirdly, all local organizations in South Lampung were still not inclined toward establishing an attempt to develop productive economy within the society. 
Based on interviews, observations, and documentations, the mapping on community institutional indications in South Lampung revealed that participation in vasectomy method of $K B$ actually contributed to a changing relational power and societal power by launching new spaces of power. It enabled previously-marginalized people, who previously had either information or access, to find a space and improve their representativeness based on their own participations on key issues. Those spaces were created through society groups' consolidation, emergence of influential groups, and various society participations in community forums.

Table 5.

Affiliation pattern (bond) based on local institution's activity orientation

\begin{tabular}{|c|c|c|c|c|c|c|c|c|c|c|c|c|c|}
\hline \multicolumn{14}{|c|}{ Participation Form/Pattern } \\
\hline \multirow{2}{*}{ Regency } & \multirow{2}{*}{$\begin{array}{c}\text { Organization } \\
\text { Form }\end{array}$} & \multicolumn{2}{|c|}{ PP } & \multicolumn{2}{|c|}{ GM } & \multicolumn{2}{|c|}{ PDP } & \multicolumn{2}{|c|}{ PK } & \multicolumn{2}{|c|}{$\mathrm{PL}$} & \multicolumn{2}{|c|}{ Total } \\
\hline & & Num & $\%$ & Num & $\%$ & Num & $\%$ & Num & $\%$ & Num & $\%$ & Num & $\%$ \\
\hline \multirow{5}{*}{$\begin{array}{c}\text { South } \\
\text { Lampung }\end{array}$} & $\begin{array}{l}\text { Civil Society } \\
\text { Organization } \\
\text { (LSM) }\end{array}$ & 0 & 0 & 4 & 6.06 & 3 & 4.55 & 59 & 89.4 & 0 & 0 & 66 & 100 \\
\hline & $\begin{array}{l}\text { Societal } \\
\text { Organization } \\
\text { (ORMAS) }\end{array}$ & 0 & 0 & 0 & 0 & 0 & 0 & 120 & 100 & 0 & 0 & 120 & 100 \\
\hline & $\begin{array}{c}\text { Regional } \\
\text { Government } \\
\text { Organization }\end{array}$ & 0 & 0 & 0 & 0 & 7 & 100 & 0 & 0 & 0 & 0 & 7 & 100 \\
\hline & $\begin{array}{l}\text { Indigenous } \\
\text { Organizations }\end{array}$ & 0 & 0 & 0 & 0 & 0 & 0 & 365 & 100 & 0 & 0 & 365 & 100 \\
\hline & Total & 0 & 0 & 4 & 0.72 & 10 & 1.79 & 544 & 97.5 & 0 & 0 & 558 & 100 \\
\hline
\end{tabular}

Remarks:

$\mathrm{PP}=$ Politics Participation

$\mathrm{GM}=$ Mass Movement

PDP = Democratic Participation in Government

$\mathrm{PK}=$ Community Participation

$\mathrm{PL}=$ Other Participation Forms

Source: Duadji \& Tresiana 2015

This study found out that community forums are the most suitable as new spaces to be distributed in such context. Gaventa \& Valderama (2001:72) also looked closer to some form of spaces in which society participation (particularly in vasectomy method of $K B$ ) happens. They argued that society members should understand the context in which those spaces are created. They also emphasized to distinguish participations based on several factors. First, an invited space which is formed by both government or donors. Second, a popular space which is formed by society. Therefore, society members' participation, through a community forum to talk about $K B$ and vasectomy, shall signal room creation, where they can discuss thematical issues based on their knowledge and capacities. Government's attention and responsiveness become a hearing space. Such processes indicate a governance imperfection which needs frequent interactions with the mandates' givers to listen to their aspirations as a consideration in decision-making process, or even making those decisions together.

An embryo of institutional community as a popular/people forum in South Lampung regency can actually be turned into a fairly imminent power in politics and county government. Emerging institutional activities as a public space in several countries can potentially build trust and social capital between society groups, as well as to conduct knowledge transaction about vasectomy and establish a partnership between society and the government. Trisnanto, Fitriani, \& Fatih (2017:66), in a research about building social capital through Gapoktan, posited several social capital components as the driver of local institutionalization, namely identity, unity in vision and objective, trust, and openness. These components are the intrinsic values acting as the bond of collective institutionalism. 
Institutional collective action is a media to drive community members' participation in population development, specifically for $K B$. This forum is commonly used by the community members for knowledge transcation, so that collective awareness to formulate common issues and find the solutions can be cultivated. Friedmann (1987:101) illustrated these followings characteristics of community forum: 1) the existence of non-hierarchical relationship; 2) high level of social commitment from its participants; 3) tolerance to pluralism; 4) openness; 5) prioritizing dialogue and consensus-building. The additional characteristics are: 1) independence or autonomy; 2) inclusivity of public space; 4) opportunity and rights to articulate public issues; 4) space to develop one's personality or character.

Table 6.

Value trends of local institutions in South Lampung regency

\begin{tabular}{|c|c|c|c|c|}
\hline \multirow[b]{2}{*}{ No } & \multirow[b]{2}{*}{$\begin{array}{l}\text { Organization } \\
\text { Forms }\end{array}$} & \multicolumn{3}{|c|}{ Value Trends } \\
\hline & & Social & $\begin{array}{c}\text { Economy } \\
\text { (Development of } \\
\text { productive industry) }\end{array}$ & $\begin{array}{l}\text { Politics and } \\
\text { Development } \\
\text { (Governance) }\end{array}$ \\
\hline 1 & $\begin{array}{l}\text { Civil Society } \\
\text { Organization } \\
\quad(\text { LSM })\end{array}$ & Public interest orientation & $\begin{array}{l}\text { Has not yet } \\
\text { established }\end{array}$ & $\begin{array}{l}\text { Issue maker, } \\
\text { negotiating public } \\
\text { interest with the } \\
\text { government }\end{array}$ \\
\hline 2 & $\begin{array}{l}\text { Societal } \\
\text { organization } \\
\text { (ORMAS) }\end{array}$ & $\begin{array}{l}\text { Elite interest orientation, } \\
\text { societal interest }(K B)\end{array}$ & $\begin{array}{l}\text { Has not yet } \\
\text { established }\end{array}$ & $\begin{array}{l}\text { Issue maker, } \\
\text { negotiating public } \\
\text { interest with the } \\
\text { government }\end{array}$ \\
\hline 3 & $\begin{array}{c}\text { Regional } \\
\text { government } \\
\text { organization }\end{array}$ & Balancer of social power & $\begin{array}{l}\text { Providing aids in the } \\
\text { name of government } \\
\text { elites }\end{array}$ & $\begin{array}{l}\text { The instrument of } \\
\text { government power }\end{array}$ \\
\hline 4 & $\begin{array}{l}\text { Indigenous } \\
\text { organizations }\end{array}$ & $\begin{array}{c}\text { Tightly-knit and } \\
\text { harmonious, tolerant, } \\
\text { gotong royong (community } \\
\text { self-help), kinship } \\
\text { upholder, ethnically/ } \\
\text { culturally attached, } \\
\text { socially aware, balanced, } \\
\text { sustainable, obedient } \\
\text { toward indigenous leaders, } \\
\text { aware of demography issue } \\
\text { (population, including } K B \text { ) }\end{array}$ & $\begin{array}{l}\text { Has not yet } \\
\text { established }\end{array}$ & $\begin{array}{l}\text { Participation is } \\
\text { suggested, position } \\
\text { is declared, and } \\
\text { participation in } \\
\text { democracy party is } \\
\text { ensured }\end{array}$ \\
\hline
\end{tabular}

Source: Duadji \& Tresiana 2015

\section{A model to increase male participation in vasectomy method of $K B$}

Duadji \& Tresiana (2015:65) found many causes of low male participation in vasectomy method of $K B$. The causes can be derived from several factors: 1) from male factors, namely knowledge, attitude, practice, and needs; 2) from circumstantial factors, namely social, culture, society, family/ spouse, limited information, accessibility toward male contraception, and existing prejudice in the society. Many informants criticized the lack of data on $K B$ 's knowledge, attitude, and practice for males, namely to what extent a male should involve in it and what male needs from it. Therefore, in order to enhance vasectomy participation among male, a baseline to conduct a dialogue is needed, so that male needs and expectations can be identified to compose a suitable intervention policy.

Knowledge transaction in terms of vasectomy information should also be well-socialized. Male participation in shaping social behavior and gender equality in $K B$ programs is one of the objectives of $K B$ and reproductive health, where a married couple (male and female) shares responsibility in deciding their own reproductive health. Low male participation in $K B$ is caused by lack of information for a married couple regarding $K B$ and reproductive health. In fact, there has been no 
specific intervention for male $K B$ and low stimulants for male participants in $K B$. Besides, various activities related to $K B$ were mostly directed to female than male; thus, a breakthrough is needed to spur male participation, particularly in vasectomy method and gender-based reproductive health in South Lampung Regency.

Based on interview data and observation, Duadji \& Tresiana (2015:67-69) found three important dimensions to determine the increase of male participation in vasectomy. Firstly, a representative public space is necessitated, particularly a community forum in South Lampung. Friedmann (2011:73) asserted that using transactive planning approach, a public space becomes a media in constructing social awareness. A cooperation shall run smoothly, if communication is conducted through dialogues. In a transactive planning, the dialogue occurred is called life dialogue, which was further re-asserted by Innes \& Booher (2000:83) as authentic dialogue. In this context, every society member, both male and female, sits together in equal respect and empathy, so that a reciprocal and mutually beneficial relationship can be established. A dialogue can only occur if the society members participate and sit together to solve common problems. Likewise, participation in a transactive planning space can only occur if the members have common interest and opportunity to voice out their interests, as well as the existence of mutual dependence and trust. A corporation through dialogue and participation is directed toward consensus building (Woltjer 2000:121). A process containing dialogue, participation, and mutual consensus, is summarized in a collaborative process.

Secondly, informal elite support (Table 2) plays as an important factor in building awareness and knowledge transaction of vasectomy in the society. Society participation is heavily represented by community figures who comprise of the elites within the society. Society figures can be categorized as informal elites. Adi (2001:17) defined it as the uppermost position in social structures, namely in economic, education, health, government, politic, religion, teaching, and other fields. Each kind of society, both modern and traditional, usually has a small group of individual governing other society members. This group of elites can be further classified as governing elites and non-governing elites. Society itself is divided into two layers, namely elites (consisting of few members of society) and non-elites. Governing elites usually have less members than non-governing ones. In this research, society elites refer to the informal elites, such as community figures and indigenous leaders.

Third, policy support. The most important substance of vasectomy participation lays in a working participation system where a policy should earn society support and should be directed toward empowerment effort. It can be said that the purposes of developing male participation in vasectomy method of $K B$ are: 1) participation enables the creation of autonomous, independent, and selforganized society to face difficult situation and withstand disadvantageous situation; 2) participation is not only a concrete reflection of an opportunity for expression and a way to fight for it, but also a guarantee to ensure that there is no neglection of society needs. Duadji \& Tresiana (2015:81) recommended that policy support should be derived from voice, access, and control process. Through voice, $K B$ participants' rights and acts in expressing their aspiration, suggestion, needs, interest, and demand to their community and government, are expected to influence, determine, and be actively involved in the policy, particularly to ensure society's access on $K B$ service. Moreover, control determines how $K B$ participants are willing and capable of getting involved in observing $K B$ 's implementation process, so that a transparent and accountable governance for $K B$ programs can be established according to society's needs. To achieve such objectives, a communication effort needs to be conducted with related parties, so the program really takes the target groups' circumstance and needs into account. Furthermore, it is also one of the requirements to successfully implement the program and to encourage the society members to voluntarily observe its implementation in order to realize the programs' objectives. The steadier the communication efforts, the bigger chance to reach consensual perception between development's stakeholders.

Fourth, social capital refers to an awareness that conducting an economic activity cannot solely depend on human capital, physical capital, or other forms of capital. Coleman (2000:20) initiated social capital concept in his research on education and confirmed that social capital (in the form of 
expectation and obligation, network and information, and social norms) positively influences and adds to humanitarian capital, both in the family or community. Coleman emphasized on social relation as the core of social capital. He considered analysis on social capital formation provides a middleway between rational choice perspective (which viewed that social action based on self-interest) and social norm perspective (which explained that social action depends on external boundaries set by norms). To conclude, social capital is a way of reconciling individual action and social structure.

Putnam (2000:197) defined in his book that social capital is a part of social organization, like beliefs, norms, and network which enhance society's efficiency by facilitating coordinated actions. In his research, Putnam concluded that institutional performance in North Italy was relatively successful due to reciprocal relationship between government and civil society. The research revealed that a synergy between civil society and effective regional government results in a higher level of prosperity in Southern Italy. Social capitals, like education, openness, and effective institutions, contributed significantly to citizen satisfaction toward regional government. Life satisfaction is related to various forms of trust and network which may result in or encourage a high level of trust toward the government.

Fukuyama (2005:ix) highlighted that a reciprocal exchange in a network is not solely based on costbenefit principal. Instead, it happened within an informal, norm-based network which does not expect a direct reciprocal action; rather, it expected benefits in a long-term. This network was an important part of social capital. At the individual level, network members shall receive some benefits, namely improving access in information exchange, contract enforcement, and a focus on collective visions and objectives.

Then how does social capital work in vasectomy's participation context? A research by Handoyo (2013:252-266) recommended that social capitals, particularly trust and networking, contribute to dialogues and enhance lower class' participation and welfare. Fukuyama (2005:ix) revealed study findings from various countries that a strong social capital shall elicit growth in various sectors, as it triggers high level of trust and closeness among the actors in the same network. Social capital also refers to some sides of social organizations, such as trust, norms, and social networks which may facilitate collective actions. It emphasizes on society togetherness in improving their life qualities and driving a further change, as well as conducting continuous adaptation processes.

Narayan (1999:6) interpreted social capital as norms and social relationship embedded in society social structure which enable them to coordinate their actions and achieve their life objectives. Kusumastuti (2015) defined social capital as society's capability in associating with each other so they become an renowned power, not only in terms of economic aspects, but also other social aspects.

Narayan (1999:43) concluded that through social capital's lenses, cross-cutting ties between social groups and government can provide a new suggestion for upcoming government policy. Groups' social solidarity shall perform a bond (social capital's bond) which brings together individuals and resources. For an imbalanced society, cross-groups' bonds (as a bridge of social capital) are needed for social cohesion and poverty alleviation.

Based on observation data, social capitals are revealed in the form of mutual trust between society members as a result of a routine interaction between them in a neighboring community and countylevel institutions/associations. Social capitals are also seen as an opportunity to build trust in countylevel institutional and to develop social networks across counties. For neighborhood or county level of interaction, trust network is relatively narrow and personal where their kinship is generally influenced by primordial or ascriptive value. Such values were depicted in routine meeting frequency for local institutions, which was generally conducted once a month. Moreover, their attendance rate was significantly high, and the largest number of attendance was presented at consensus-based negotiation (musyawarah), Koran recitation, Gapoktan and LKMD meetings. Each meeting and discussion had their own agenda. For consensus-based negotiation, they usually emphasized on 
county-level issues, such as farming; animal husbandry; making organic fertilizers; crop prices among farmers; plant fertility; how to plant; how to cultivate lands; rural governance development; progress of their village; and population-related issues. While Gapoktan focused its discussion to increasing agricultural and livestock productivity; utilization of organic fertilizer and generic fertilizer; seed procurement; fertilizer; corn nursery; cow waste or sewage treatment; workshops on agriculture, plantation, and livestock; harvest management and marketing; improving productivity; and loan evaluation. Moreover, social gatherings of rural social institutions emphasized on the discussion of road construction, development priorities in the village, improving the competence of village human resources, discussing village development programs, village work plans, and evaluation of the village development work. For mothers, they had an organization called Family Welfare Movement (PKK) focusing on improving family welfare. It was conducted monthly with several activity agendas, such as counseling on healthy and clean lifestyle; cleaning the environment; reciting yasin and tahlil; establishing a center for pre- and post-natal health care and information (posyandu); overcoming malnutrition; and improving mother and children's life skills. These communities illustrated: 1) an enforcement of humanistic social system (non-exploitative and intimidating towards humans or society members; 2) an enforcement of justice system aimed to fulfill human's basic needs (not imperialistic and negating social life); 3) begin to establish a solidarity system based on mutual trust between the elements of the community system; and 4) begin to develop opportunities to realize a relatively high degree of independence and community sustainability as one of the most important parts of a society.

Based on the Figure 1, it can be seen that social capitals are shaped and transmitted by cultural mechanism, such as religion, tradition, or historical custom by adopting some virtues, such as loyalty, honesty and dependability. The roles of indigenous leaders and society figures (informal elites) as transformational leaders are necessary to influence the society members through changing status quo, enhancing individual creativity, inspiring and motivating, and expressing idealism. Some mentoring programs also strengthen the existing social capitals. The society members sense some benefits, such as improvement of knowledge, experience, harmony, increased self-reliance, environmental sustainability, infant health, unity, exchange of experience, cohesiveness, friendship, program sustainability, improved communication, community aspirations, and improved community welfare.

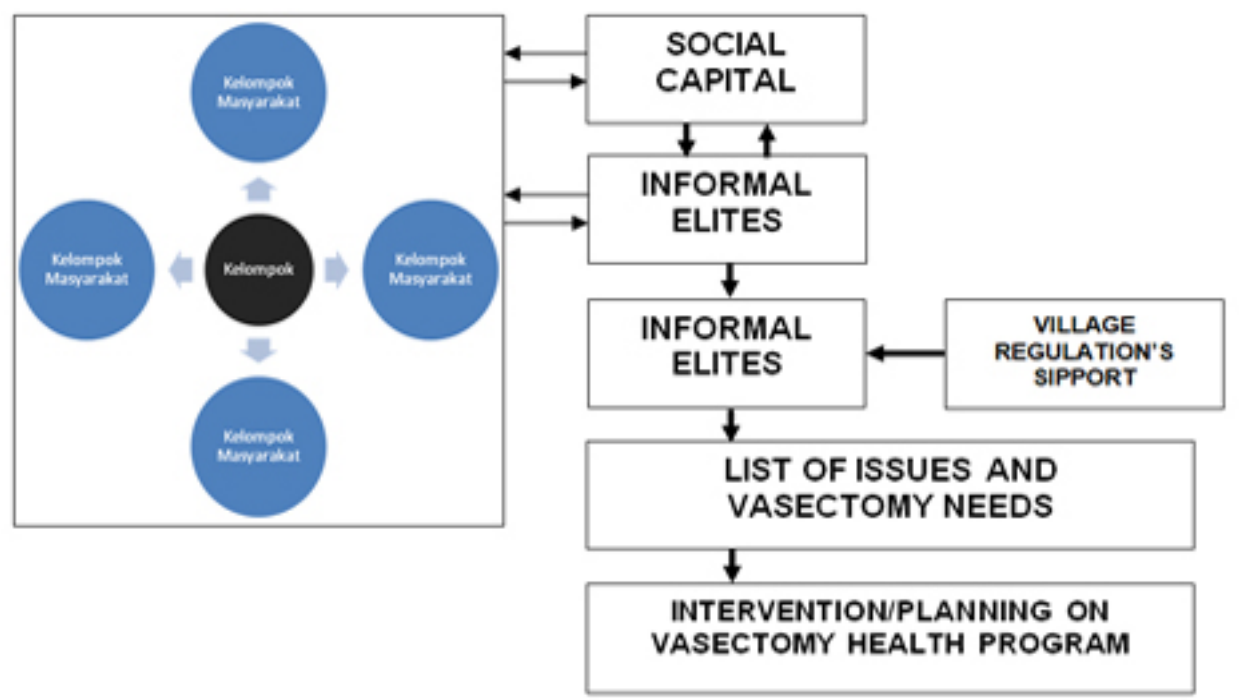

Figure 1.

Community Forum Model as an effort to provide transaction space and knowledge transfer

The determination of a community forum model is derived from the analysis and several findings from the observations. Firstly, the root of the problem for low participation was due to institutional weakness, particularly for governmental authority (bureaucracy) as an autocratic institution. 
Therefore, to overcome this weakness, it is necessary to establish a representative and familiar space as a medium of knowledge transfer and transactions. Secondly, the existing local institutions were developed and became a need for the society members. Public expectations on them is a key point where activism and awareness to participate actively in interaction process and egalitarian knowledge transactions can become more intertwined and visible.

Figure 1 explains the urgency of a community forum as a social transactions space, because this institutional capability is expected to effectively play a role in mobilizing understanding, knowledge, arguments and ideas towards consensus building, as well as a preliminary collective action to increase participation in vasectomy method of $K B$. To achieve maximum capacity of the community forum, several supporting instruments are needed: 1) government support in the form of village regulations to strengthen knowledge/knowledge transaction forum; 2) the role of informal elites, both community figures and indigenous leaders, in the context of instruction and exemplary attitude; and 3) social values among citizens.

The idea of institutional development model, which is related to the use of new spaces for dialogue and community involvement in knowledge transactions, is aligned and conformed to Denhardt \& Denhardt's statement (2013:51). Based on their new public service perspective, service starts from the important position of citizens as government owners and their ability to act together to fight for a greater good. New public services seek common values and common interests through widespread dialogue and civic engagement. A new form of space for the successful improvement of vasectomy participation is through the formation of a community forum, where the citizens can speak about family planning issues based on their respective knowledge and capacity. On the other hand, the attention and responsiveness of the rural government provide a space for a hearing, proving that no power is perfect and requires daily interactions with the citizens to listen to their voices and to consider their opinions in policy-making decisions, or even to formulate a joint decision. It is exactly where the space called by Denhardt \& Denhardt (2013:52) as the space of power occurs. Duadji \& Tresiana (2015:70) pointed out that the presence of community forums in South Lampung can be used to solve the lack of knowledge in reproductive health, reproductive rights, and vasectomy, as well as to seek solutions for community problems and highly expected to provide recommendations to perform certain actions.

\section{Conclusion}

Low participation for male vasectomy method of $K B$ as an attempt to achieve equality and equal reproduction was caused by non-existent information transaction and public space as an important stimulant. An important element to achieve it is through a formation of institutional collective action (community forum) as a representative, familiar, and social-based institutional development model to generate community participation in the context of population development and $K B$. Community Forum Model serves as a media for knowledge transaction to improve common awareness, formulate common problem, and find some solutions for community problems.

In order to achieve the aforementioned objectives, these following instruments are necesssary: 1) the role of indigenous leaders and society figures becomes the main capital to create and run the forum; 2) the support of social capital through some mobilization efforts by indigenous leaders and society figures; and 3) the support of village regulation to advocate the community forum as a legitimized media to conduct a dialogue and encourage public participation.

\section{References}

Adi IR (2001) Pemberdayaan, Pengembangan Masyarakat dan Intervensi Komunitas (Pengantar Pada Pemikiran dan Pendekatan Praktis). Jakarta: Fakultas Ekonomi Universitas Indonesia.

BKKBN Propinsi Lampung (2014) Laporan Peserta KB Pria dan Kesehatan Reproduksi Tahun 2014. Bandar Lampung. Tidak dipublikasikan. 
Coleman JS (2000) Social Capital in The Creatin of Human Capital. In Partha Dasgupta and Ismail Serageldin. Social Capital A Multifaceted Perspective. Washingston DC.

Denhardt J \& Denhardt R (2013) Pelayanan Publik Baru: Dari Manajemen Steering ke Serving. Yogyakarta: Kreasi Wacana.

Duadji \& Tresiana (2015) Laporan Akhir Penelitian Hibah Institusi Model Peningkatan Partisipasi KB Vasektomi di Kabupaten Lampung Selatan. Lembaga Penelitian dan Pengabdian Masyarakat Universitas Lampung. Tidak dipublikasikan.

Fukuyama F (2005) Memperkuat Negara. Jakarta: Gramedia.

Friedmann J (1987) Planning in the Public Domain: From. Knowledge to Action. New Jersey, Princeton University Press.

Friedman J (2011) Insurgencies, Essay in Planning Theory. London and New York: Routledge

Gaventa J \&Valderama C (2001) Participation, Citizenship and Local Government: Background note prepared for workshop on Strengthening participation in local govermance. Institute of Development Studies.

Handoyo E (2013) Kontribusi modal sosial dalam meningkatkan kesejahteraan Pedagang Kaki Lima pasca rekolasi. Journal Komunitas, 5 (2):252-266.

Healey P (1997) Collaborative Planning: Shaping Places in Fragmented Societies. London: Macmillan Press LTD.

Huruta \& Sasongko (2016) Uang dan ruang yang berkelanjutan dalam pembentukan Badan Usaha Milik Desa (BUMDes). Masyarakat, Kebudayaan dan Politik, 29 (4):212-222.

Innes JE \& Booher DE (2000) Collaborative Dialogue as a Policy Making Strategy, Institute of Urban and Regional Development UC Berkely, IURD Working Paper. [Accessed 13 December 2010]. http://escholarship.org/uc/item/8523r5zt.

Kusumastuti A (2015) Modal sosial dan mekanisme adaptasi masyarakat pedesaan dalam pengelolaan dan pembangunan infrastruktur. Jurnal Sosiologi, 20 (1):81-97.

Miles M \& Huberman AM (1992) Analisis Data Kualitatif, Terjemahan Tjetjep Rohandi Rohidi. Jakarta: UI Press.

Narayan D (1999) Bonds and Bridges Social Capital and Poverty (Policy Research Working Paper 2167). Washington DC: The World Bank.

Putnam RD (2000) Bowling Alone The Collapse and Revival of American Community. New York: Simon and Schuster Paperbacks.

Sutinah (2017) Partisipasi laki-laki dalam program Keluarga Berencana di era masyarat postmodern. Masyarakat, Kebudayaan dan Politik, 30 (3):289-299.

Tresiana N \& Duadji N (2016) Kegagalan pemaknaan "Lembaga Musyawarah Perencanaan dan Pembangunan Desa" dalam mewujudkan deepening democracy. Masyarakat, Kebudayaan dan Politik, 29 (4):191-203

Trisnanto F \& Fatih (2017) Membangun modal sosial pada gabungan kelompok tani. Masyarakat, Kebudayaan dan Politik, 30 (1):59-67.

Woltjer J (2000) Consensus Planning, Therelevance of Communicative Planning Theory in Dutch Infrastructure Development. Hampshire: Ashgate Publ. Limited 